\title{
Post-COVID-19: A Time of Opportunity for Asian Universities
}

\author{
Eden Y. Woon
}

\section{Scene Setter-Global}

By the end of 2019, IAU member universities were already grappling with a variety of issues and knew that 2020 was going to be a challenging year. But many of them were still optimistic and looked forward to IAU's 70th Anniversary Year when universities would continue to push forward the frontiers of knowledge and play an increasing role of providing young people an understanding of the world beyond their hometown. And the key of this optimism was based on increased internationalization.

At that time, globally, there were 5.3 million international students. For top research universities in the USA, the percentage of international students was around $20 \%$, with Chinese and Indians being, by far, the most numerous, especially in postgraduate science and engineering departments. In the UK and Europe and Australia, there was increasing dependence on students from Asia. Universities' finances came to be very dependent on income from international students. For example, in the USA alone, one statistic calculated that every seven international students generated three jobs, providing US\$41 billion to the economy per year UNESCO (2019), NAFSA (2019).

Top universities were busy signing up student exchange partners, and international exchange experiences became something sought after by many students, although there was no doubt that the opportunities were limited to those who could afford the foreign travel and living expenses. And universities found dual degree programs and combination/unified programs to be excellent ways to contribute towards research cooperation.

Speaking of research, cross-border collaborations were numerous, and thousands of research publications had authors from different countries per year. Visiting scholars, both short term and long term, were going back and forth between countries

\footnotetext{
E. Y. Woon $(\bowtie)$

Asian Institute of Technology, Khlong Nueng, Thailand

e-mail: president@ait.asia 
and continents. But, this global outreach expanded both for academic and financial purposes. Seminars, workshops and conferences not only increased academic cooperation but allowed non-academic audiences from afar to be trained in a variety of subjects and skills.

\section{Scene Setter-Asia}

By the beginning of 2020, China, Japan, Korea, Hong Kong, and Singapore had universities ranked in the top 50 of the world in prestigious university rankings. Taiwan's universities have for decades sent top graduates in science and engineering to the US. Universities in Israel helped make the country into a "Starter Nation". India's technical institutes provided many top graduates to global technology institutions and companies, and Japan remained among the world's top producers of Nobel Prize laureates. Turkey, Iran, and Saudi Arabia were catching up fast in academics. Universities from other parts of Asia, like Thailand, Vietnam, Indonesia, Malaysia, and the Philippines, although they saw some of the better students from their home countries going to the West for undergraduate and graduate education, were themselves steadily improving their scholarly standing.

Top global universities continued to show an interest in Asia, both for the talent that could feed into their laboratories and for collaboration with increasingly substantive universities in Asia, although establishment of branch universities in Asia slowed in recent years.

Many Asian universities created regional alliances. They also reached out to the world and became active participants of significant international alliances such as the IAU. Collaboration in research and dual degrees between Asian universities and topranked global universities became more frequent, thereby lifting the standards for all. But, internationalization also still meant "westernization", since the top-ranked universities continued to be much more numerous in the West, whereas many top students came from Asia which provided much of the research and creative-and even management-talents that fuel the innovative industries of the West.

\section{Clouds on the Horizon}

But, for universities around the world, there were already clouds in the sky before 2020. First, the demographics were working against them. Young people of collegeage were diminishing in number in an aging society. Whether in China or Japan, the United States or the UK, this is worrisome for enrolment. Funding for all universities became tighter as taxpayers demanded more immediate "payback" for their money, and thus governments started to impose "Key Performance Indicators" to ensure more "accountability", something many universities were concerned with as it could 
encroach on academic freedom Quacquarelli (2019), Locke (2015:256-257), Hao (2015:121). Funding for fundamental research became harder and harder to obtain.

The fight for top students intensified between the top universities in Asia and the top universities of the West, with the latter increasingly dependent on international students from Asia for their research, education, and finances. And this competition began to tip in favour of Asian universities when many countries in the West tightened their visa rules on work-after-graduation — a big attraction for Asian students wanting to study in the West.

With growing populism and a general push-back against globalization, combined with geopolitics starting to interfere with the free flow of students and research talent, with universities' financial stability being shaky, the clouds were gathering, while we were in the "golden age of universities" at the end of 2019 and looking forward to celebrating IAU's 70th Birthday!

\section{COVID-19 Arrival}

In January 2020, the Covid-19 pandemic began to sweep the globe. Universities around the world scrambled to make sure their faculty, students, and staff were safe from the virus, and they closed down soon after, putting courses online. Internationalization efforts were halted, from student exchanges to research visits to international conferences. During the summer, universities were consumed with decisions on whether to open in the Fall, how to keep the campus safe, and how to manage education online. With the pandemic raging globally and travel, visa, and health restrictions proliferating, the result was a huge disruption to student lives, the recruitment "supply chain", and universities' finances. Research collaboration was badly affected, although academic exchanges and dialogue were actually able to continue through online forums and Zoom webinars.

In April 2020, the Asian Institute of Technology (AIT) came up with the Pipeline Partnership Program (PPP) which offered partner universities the opportunity to temporarily place some of their Asian students on AIT campus (for a semester or a year), whilst waiting for the virus situation to clear up in these partners' countries. After completing a residential period at AIT, these students can go to their destination universities when those countries' virus situation improves. This PPP can also morph into a $1+1$ dual master's degree or a $2+3$ master's/PhD degree for students to spend the initial period on the AIT campus and then go to other campuses later. Since then, due to the effect of the Coronavirus, several global universities have engaged in similar versions of PPP, with Cornell having the "Study Away" program with their students studying initially at partner universities around the world before coming to Ithaca, and NYU and Duke using their China branch campuses to accommodate their new Chinese intake for a while (Cornell Chronicle 2020; NYU Shanghai 2020; Duke University 2020).

With the Covid-19 pandemic raging even in the third quarter of 2020, there is an increasing realization that we are looking at a global environment which will be 
fundamentally different for several years, or even longer. The reference to a New Normal is now prevalent. Therefore, universities are not only scrambling to prepare for Fall semester 2020, they have begun to engage in sobering thinking about the future of their institutions. The big question is what is the value of a university education in the future? But, the sub-questions many will be asking themselves in the next three to five years range from recruitment to talent flow, internationalization, the value of residential universities, research collaboration, more use of technology in education, and the future business model.

As Asian universities address these questions, they will find that they can actually take advantage of the environment post-Covid-19, using technology, its geographic centrality, its growing economies, the abundance of bright students and scholars, and with more and more universities in this continent taking their place among the top in the world.

\section{How Asia Can Take Advantage}

1. Recruitment-Many students are now unable to go to the West for university education from heavily infected Asian countries. Now Asian universities can recruit more good quality students from their home country and neighboring countries. Universities in China, India, Taiwan and Singapore will especially benefit, at least in the short term. AIT has, in fact, doubled its Chinese student enrolment in Fall Semester 2020. And others can emulate the PPP to provide a regional partnership for top universities in the West. We expect dual degrees to flourish between Asian universities and Western universities. Student quality will definitely go up in many Asian universities in the next 3-5 years, allowing these universities to build up their academic reputation.

2. Talent Flow-We are likely to see a long-term change in talent flow and mobility coming from the West to Asia. Already, exacerbated by the geopolitical tension between the US and China, there is an effect on student recruitment. Furthermore, this sentiment extends to many successful research scientists originally from China currently in the US, who are starting to come home to lucrative opportunities in Chinese universities. Work-visa restrictions and a perceived lessthan-welcoming attitude towards Asians can discourage Asian talent from staying in the West. More will come home. This reverse brain drain will definitely help many Asian universities.

3. Internationalization-With technology providing many new internationalization experiences with wider access, more students in Asia, including the less well-todo, can benefit. Since there will be less travel for everyone, we need to maximize the "foreign exposure" of students through technology. We already mentioned above about accessing partner universities' classes via technology, and that can also extend to campus experience, with more virtual tours of campus facilities and local sights, more remote conversation with students across the globe, more participation in cross-border online activities, all to simulate a "presence" in 
a foreign land. These virtual exchanges can be more real than ever. Without traveling, using technology, ironically, accessing global universities is easier for more Asian students.

4. Education Collaboration-Asian universities can take advantage of technology to maintain dynamic global access. For example, AIT will be using Hybrid Instruction this Fall, with students both in the classroom and online. The latter, who are overseas initially, will have as good a residential classroom experience as possible. AIT plans to use Hybrid Instruction beyond Fall to integrate continuing education with academic programs, to provide flexibility for work-study students, and to allow international partnerships in lectures and classrooms with blended learning. The facility can provide scalability and flexibility to profoundly increase education across borders at a lower cost, making more inclusion possible. Modular delivery of programs can provide options and flexibility, with participation by overseas non-degree students. In short, there can be diversified and multiple options from different countries and universities, facilitating dual and joint degrees.

5. Research Collaboration-Since travel will be discouraged, the timeframe of exchanges of faculty members and researchers will be longer, allowing deeper collaboration between Asian universities and those in the West. Sharing of visiting faculty resources is essential as migration of faculty will be lessened in the future, either for health or geopolitical reasons. Longer visits by top faculty help to bolster the quality of Asian universities. For research, virtual laboratories and teaming up with students in laboratories across the globe and other simulation and artificial intelligence initiatives all can go a long way to complement in-presence research work. Zoom and other online platforms will become commonplace for academic discussions and collaborations across continents.

6. Complementary Collaboration-One particular method to foster collaboration is what can be called "complementary collaboration", where leading-edge technology in the West can be applied to sustainability issues - many of which are critical in Asia and being tackled by Asian scientists. AI as applied to climate change problems, or robotics applied to agriculture, come to mind. With problems involving nature, from Covid-19 to climate change seriously affecting humans globally, research on the Sustainable Development Goals will be emphasized more. These are fertile areas of complementary collaboration.

7. Regional Alliances - These will strengthen. With better students, better faculty, more certainty on public health, many Asian universities with a good academic base can already gain in this post-Covid-19 environment. And they can form more alliances and dialogue groups with each other, taking advantage of exchanges nearby. Universities in Asia will not only look to the West for collaboration but engage in more collaboration with universities within the region. They will need to be open-minded and look within the region for the acceptance of transfer credits and qualifications, including setting up regional funding schemes like an "Asian Erasmus", for example.

8. Asia's Importance-Universities in Asia can take advantage of Asia by playing a key role in working with not only local companies but also multinationals 
interested in the Asian market. They may not easily access Asian students in their HQ country but can draw on the students in Asia to help their companies in Asia. There will also be more opportunities to work with the private sector by providing continuing education to senior staff who may not travel as readily to multinationals' HQs, and we can use online modes of partnership or even "hybrid internship". In short, when travel is restricted, the unique position of Asia being a huge market and a rapidly developing region can foster closer ties of the private sector with increasingly respected Asian universities.

\section{Into the Future}

Universities in Asia, being younger, less established, increasingly respected, more dynamic, and eager, with a great geographic position and a large number of smart young populations eager to learn, with the embrace of more technology in education, can actually gain out of this crisis. Covid-19 may be a depressing chapter in the history of the human race, but its pervasive and lingering impact is moving, ever so slightly, the global centre of gravity of academic excellence towards Asia. Every crisis is an opportunity, and this is a time of opportunity for Asian universities.

\section{References}

Cornell Chronicle. (2020). 'Study Away option supports international students'. Retrieved from https://news.cornell.edu/stories/2020/07/study-away-option-supports-international-students.

Duke University. (2020). 'Message to Duke '24 International Students: DKU Option for Fall 2020'. Retrieved from https://dkurelations.duke.edu/students/duke-students-dku/messageduke-24-international-students-dku-option-fall-2020.

Hao, Zhidong. (2015). 'Commercialization and Corporatization Versus Professorial Roles and Academic Freedom in the United States and Greater China', Chinese Sociological Review, 47:2, p. 121.

Locke, Kirsten (2015). 'Performativity, Performance and Education', Educational Philosophy and Theory, 47:3.

NAFSA (2019). 'Despite Stagnant Enrolment, International Students Contribute Nearly \$41 Billion to the U.S. Economy'. Retrieved from: https://www.nafsa.org/about/about-nafsa/new-nafsadata-despite-stagnant-enrollment (26.08.2020).

NYU Shanghai. (2020). 'NYU Shanghai to Host Students from NYU and NYU Abu Dhabi in Shanghai This Fall'. Retrieved from https://shanghai.nyu.edu/news/nyu-shanghai-host-studentsnyu-and-nyu-abu-dhabi-shanghai-fall.

UNESCO: Institute for Statistics. (2019) 'Outbound internationally mobile students in 2017'. Retrieved from: http://data.uis.unesco.org/Index.aspx?queryid=172 (26.08.2020).

Quacquarelli Symonds (QS). (2019). 'How Aging Populations are Impacting the Higher Education Sector'. Retrieved from: https://www.qs.com/aging-populations-impacting-the-he-sector/ (26.08.2020). 
Eden Y. Woon became the President of Asian Institute of Technology (AIT) on September 1, 2018. He also serves as Special Advisor to the Shaw Foundation in Hong Kong. From 2010 until November 2017, Dr Woon was the Vice-President for Institutional Advancement of the globally highly-ranked Hong Kong University of Science and Technology (HKUST), responsible for international relations, China affairs, development, alumni, and public relations. Before HKUST, Dr Woon had a career in the military, government, business, and academia.

Open Access This chapter is licensed under the terms of the Creative Commons Attribution 4.0 International License (http://creativecommons.org/licenses/by/4.0/), which permits use, sharing, adaptation, distribution and reproduction in any medium or format, as long as you give appropriate credit to the original author(s) and the source, provide a link to the Creative Commons license and indicate if changes were made.

The images or other third party material in this chapter are included in the chapter's Creative Commons license, unless indicated otherwise in a credit line to the material. If material is not included in the chapter's Creative Commons license and your intended use is not permitted by statutory regulation or exceeds the permitted use, you will need to obtain permission directly from the copyright holder. 